\title{
Comparison of Large White pigs with crossbred pigs sired by French or German Pietrain boars in fattening and carcass traits
}

\author{
C. LEGAULT ${ }^{(1)}$, J. GRUAND, Geneviève LE HENAFF ${ }^{(1)}$ \\ Institut National de la Recherche Agronomique \\ (1) Station de Génétique quantitative et appliquée, 78350 Jouy-en-Josas \\ (2) Station Expérimentale de Sélection Porcine, 86480 Rouillé
}

\begin{abstract}
Crossbred slaughter pigs issued from French Pietrain (FP) or German Pietrain (GP) boars and Large White $\times$ French Landrace sows were compared for fattening and carcass traits with control Large White "Poitou " (LWP) purebreds. Three or four females or castrated males were sampled per litter. A total of 91 half-FP, 100 half-GP and 109 LWP pigs, fed ad libitum from 30 to $100 \mathrm{~kg}$ liveweight, completed the test. The $8 \mathrm{FP}$ and the $9 \mathrm{LWP}$ sires had been chosen among the upper $20 \%$ of boars performance-tested in central stations, in accordance with the current French regulations for A.I. boars. The $8 \mathrm{GP}$ boars had been bought in West Germany on the basis of combined on-the-farm testing. The comparison between half-FP and half-GP pigs did not reveal any significant difference, except for meat quality (1.5 percentage points in favour of half-GP pigs for the predicted technological yield of Paris ham processing). Half-FP and LWP pigs did not significantly differ in the latter trait. Though no significant difference was found in average daily gain on test, food conversion ratio was improved by .17 and $.26 \mathrm{~kg}$ feed $/ \mathrm{kg}$ gain in half-FP and half-GP pigs respectively, as compared to LWP pigs. This is to be related to the lower daily feed intake (about $-.2 \mathrm{~kg}$ ) in half-Pietrain pigs. Regarding carcass traits, the differences found between LWP and half-Pietrain pigs favoured the latter in a highly significant manner. HalfPietrain pigs gave heavier and shorter carcasses $(+1.7$ points in killing out percentage and $-34 \mathrm{~mm}$ in carcass length) and exhibited a higher lean content and a lower fat content (4.4 and - 4.6 percentage points, respectively). The advantage of half-Pietrain over LWP pigs in terms of gross margin per pig amounted to about $50 \mathrm{FF}$.
\end{abstract}

\section{A general report on the evaluation of crossbred European Chinese sows under field conditions in France}

\author{
R. GUEBLEZ ${ }^{(1)}$, Laurence BRUEL ${ }^{(2)}$, C. LEGAULT $^{(3)}$
}

(1) I.T.P., Pôle Amélioration de l'Animal, B.P. 3, 35650 Le Rheu.

(2) Chambre d'Agriculture des Deux-Sèvres, 79009 Niort Cedex.

(3) INRA, Station de Génétique quantitative et appliquée, 78350 Jouy-en-Josas.

A total of 234 Meishan $\times$ Large White and 219 «1/4 Meishan-3/4 Large White » sows used in 65 commercial herds were compared to crossbred Large White $\times$ French Landrace contemporary sows for reproductive traits. In addition, samples of fattening pigs from this design were sent to central progeny test stations. A within-sire comparison for production traits was made, involving respectively 86 " $1 / 4$ Chinese" vs 77 control pigs, (from 36 common sires) and $101 \ll 1 / 8$ Chinese » vs 100 control pigs (from 54 common sires).

«Half-Chinese » sows proved to produce markedly larger litters : about 3 total born and 2 weaned piglets above European contemporaries. The superiority of « 1/4 Chinese sows " was only 1 piglet at birth and 0.5 at weaning.

Fattening performance of « $1 / 4$ Chinese » or « $1 / 8$ Chinese » pigs did not significantly differ from that of control pigs though in both cases, growth and food conversion were poorer (approx. $-25 / \mathrm{g} /$ day in A.D.G. and $+0.06 \mathrm{pt}$ in F.C.R.). Differences in carcass merit were highly significant and coherent : lean tissue percentage decreased by $4.2 \%$ for " $1 / 4$ Chinese " pigs and $2.5 \%$ for " $1 / 8$ Chinese " pigs. There was also a decrease in killing-out percentage (-0.5 to $-1.0 \%$ ). The " $1 / 4$ Chinese " pigs had a slightly better meat quality but no superiority was shown by « $1 / 8$ Chinese » pigs in this respect. 